JOURNAL OF SECURITY AND SUSTAINABILITY ISSUES ISSN 2029-7017 print/ISSN 2029-7025 online 2020 March Volume 9 Number 3 https://doi.org/10.9770/jssi.2020.9.3(15)

Scopus

\title{
THE INTERACTION BETWEEN THE HUMAN RESOURCES MOTIVATION AND THE COMMITMENT TO THE ORGANIZATION
}

\author{
Mariana Petrova $^{1 *}$, Viktor Koval ${ }^{2}$, Milena Tepavicharova ${ }^{3}$, Anastasiia Zerkal ${ }^{4}$, \\ Andrii Radchenko ${ }^{5}$, Nataliia Bondarchuk ${ }^{6}$ \\ ${ }^{1}$ St. Cyril and St. Methodius University of Veliko Tarnovo, 5000 T.Tarnovski 2 Street, Veliko Tarnovo, Bulgaria \\ ${ }^{2}$ Odessa Institute of Trade and Economics of Kyiv National University of Trade and Economics, 65070 Odessa, Ukraine \\ ${ }^{3}$ Higher School of Security and Economics, 13 Kuklensko Shose Blvd., 4004 Plovdiv, Bulgaria \\ ${ }^{4}$ Classic Private University, 69123 Zaporizhzhya, Ukraine \\ ${ }^{5}$ Zaporizhzhia Polytechnic National University, Zhukovsky Street, 64, 69063 Zaporizhzhia, Ukraine \\ ${ }^{6}$ Dnipro State Agrarian and Economic University, S.Efremov str., 25, 49600 Dnipro, Ukraine
}

E-mails: ${ }^{1} m . p e t r o v a @ t s . u n i-v t . b g$ (corresponding author), ${ }^{2} v i c t o r-k o v a l @ u k r . n e t,{ }^{3}{ }^{3}$ _ivanova_zlatanova@abv.bg,

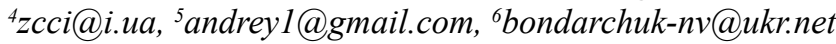

Received 15 February 2019; accepted 18 January 2020; published 30 March 2020

\begin{abstract}
Achieving positive production and economic results in the businesses is no longer a product of the efforts of an organic circle of people, but a result of the activity of the members of the entire organization. Thus, the issue of employee motivation and commitment to the business entity becomes one of the basic prerequisites for the organizational efficiency and success. The lack of motivation and attachment to the goals of the company lead to increased staff turnover and reduced efficiency. This makes the investment of training, qualification and professional development of the human resources meaningless. The aforementioned necessitates the study and analysis of the main factors, which determine the people's behavior at work, their motivation and involvement in the business entity.The purpose of this research is to investigate the relationship between the motivation of human resources and their commitment to the business organization. Establishing the interaction between the different determinants is essential in practical terms, as it allows one to predict the appearance of a certain attitude or behavior in the presence of the others.
\end{abstract}

Keywords: motivation; commitment; human resources; business organization, social responsibility, organizational effectiveness, communication, agreement

Reference to this paper should be made as follows: Petrova, M., Koval, V., Tepavicharova, M., Zerkal, A., Radchenko, A., Bondarchuk, N. 2020. The interaction between the human resources motivation and the commitment to the organization. Journal of Security and Sustainability Issues, 9(3): 897-907. https://doi.org/10.9770/jssi.2020.9.3(15)

JEL Classifications: J24, J21, D23, E24

\section{Introduction}

The socio-economic changes in Bulgaria in recent years have had a significant impact on the status and development of the business entities. This also influenced the manner of performance of the tasks, the role of the participants in its implementation, their expectations, values and skills. The managers faced challenges requiring new solutions. A reconsideration of values related to the individuals ${ }^{6}$ behavior at work, their satisfaction and sense of empathy, have proven to be crucial for the success of the management team and the viability of the company as a whole. They also contribute to its innovation and gaining a competitive advantage on the market (Pukala \& Petrova, 2019; Aktan et al., 2018). 
The scientific achievements, which explore the issue of employee motivation and commitment to the business entity, show significant results in the comprehension and structuring of this subject (Petrova et al, 2018; Islamgaleev, 2019; Zahars \& Stivrenieks, 2018; Koval et al., 2019; Tumalavičius et al., 2017; Bernardi, 2019; Borisov et al., 2018; Lorincová et al., 2019; Hermawan, Gunardi, 2019).

Modifications in the content of work, in employees and in organizations have also necessitated a change in traditional human resource management models. They relate mainly to the integration of the members of the organization to make maximum efforts to achieve the common organizational goals. Achieving positive production and economic results in the businesses is no longer a product of the efforts of an organic circle of people, but a result of the activity of the members of the entire organization.

Thus, the issue of employee motivation and commitment to the business entity becomes one of the basic prerequisites for the organizational efficiency and success. The lack of motivation and attachment to the goals of the company lead to increased staff turnover and reduced efficiency. This makes the investment of training, qualification and professional development of the human resources meaningless. The aforementioned necessitates the study and analysis of the main factors which determine the people's behavior at work, their motivation and involvement in the business entity.

Bulgarian and foreign researchers (Gryshova et al, 2019; Labunska et al., 2017; Islamgaleyev, 2018a; Islamgaleyev, 2018b; Odinokova et al., 2018; Gryshova et al, 2016a; Gryshova et al, 2016b; Hlushko et al, 2015) noted that in the innovation economy, the efficiency evaluation based on multiple criteria is a more complicated option, but on the other hand, this evaluation gives more insight into the real state. In this sense, the guarantee of the sustainability and development of the business organizations is only possible by building an effective system of selection of the management personnel. In the context of the systematic approach, it is of paramount importance to develop a model for selecting a management team to ensure the sustainability and development of the business organizations.

The problems of social partnership were considered by many specialists (Lazarova et al, 2015; Petrova et al, 2018; Androniceanu \& Tvaronavičienė, 2019). Promotion of economic educational services in Bulgaria were considered by Odinokova et al (2018), Vazov (2019).

Cooperation of entrepreneurs with institutions of vocational and higher education is viewed as close interaction between the educational and the private sectors (Uteubayev et al, 2018; Islamgaleyev \& Uruzbayeva, 2018; Girdzijauskaite et al., 2019).

Knowledge transfer between universities and business will work best where there is a general framework of cooperation and mutual understanding, involving partnerships, joint projects and the exchange of people, respectively using social environment aspects (Zemlickiene et al. 2017; Tvaronavičienè, Razminienė 2017; Bublienè et al, 2019).

The effective management is a guarantee of lasting and competitive advantage. It is implemented in accordance with the targets and strategies of the organization, through the performance of a number of management functions and tasks related to planning, selection, evaluation, adaptation, informing, organization, leadership and motivation.

The motivation is key to understanding human behavior at work and is a prerequisite for efficiency in the job. It is influenced by a number of reasons, both personal and organizational. However, motivation often is narrowed down only to the needs of the individual or is considered only through the aspect of financial rewards and incentives, without regarding it as a complex phenomenon which involves many aspects. To gain a fuller understanding, on the basis of which appropriate systems for motivation and retention of qualified personnel can be introduced, it is necessary to analyze each of these components, taking into account the interaction between them, as well as their influence on motivation (Ilieva, 2009). 
The issue, related to the necessity of research and increase of the motivation for the work of human resources, is becoming extremely relevant and important for the effective and successful functioning of the business organizations today. Despite the indisputable importance of motivation at work, despite the recognition of the importance and the role of the organizational structures responsible for the social, economic and spiritual commitment of the human resources to the companies, the problem of research and increase of their cooperation remains poorly understood, especially nationally (Davidkov, 2009). In the past ten years, Bulgaria has almost lacked research and publications to examine and study the motivation of the human resources and their involvement in the business entity.

The purpose of this study is to investigate the relationship between the motivation of the human resources and their commitment to the company. Establishing the degree of interaction between the individual determinants is essential in practical terms, as it allows one to predict the occurrence of an attitude or behavior, at the presence of other. From this perspective, this study presents an alternative view on the relationship between motivation and commitment of the human resources, ensuring organizational effectiveness and success.

\section{Material and method}

In order to study the interaction between the motivation of the human resources and their commitment to the business, 108 individuals were interviewed from seven different in size, status and type of ownership business entities in Bulgaria:

1. Р2Р ЕООД - Sofia

2. М - AGRO 2013 ЕООД - Sofia

3. GT Fast Trans ООД - Petrich

4. А\&Т ООД - Burgas

5. Сарsico ООД - Parvomay

6. LDJ - Nikolay Markov ET - Sofia

7. Gabi - Aleksandar Marinov ET - Sofia

According to their size, the surveyed business organizations are grouped into three groups, and namely:

- Up to 10 employees - $57.14 \%$

- From 11 to 50 employees $-28.58 \%$

- Over 51 employees - $14.28 \%$

By economic sectors, the companies are allocated as follows: $14.28 \%$ of the Industry sector (Clothing Manufacturing), $57.14 \%$ of the Services sector (hotel, restaurant and commerce) and $28.58 \%$ of the Agricultural sector (grain and vegetable production).

According to their legal structure, the business entities are grouped into three groups: The first one includes enterprises as Sole Traders (28.58\%). These are mostly small companies where the bulk of the production is intended for the local markets. The second and third groups are capital companies. These are Single-Member Limited Liability Companies (28.58\%) and Limited Liability Companies (42.84\%). In these legal and organizational structures, the basic factors for achieving good economic results are vocational education, qualification and production experience.

The sample covers $89 \%$ of the employees in the companies, which enables us to recognize it as being representative. The main characteristics of the survey participants are presented in Figure 1. 


\begin{tabular}{|c|c|c|c|}
\hline Age & Education & $\begin{array}{l}\text { Professional } \\
\text { experience }\end{array}$ & $\begin{array}{c}\text { Professional } \\
\text { position }\end{array}$ \\
\hline $\begin{array}{l}\text { From } 16 \text { to } 35 \text { years - } \\
\mathbf{2 1 , 4 3 \%} \\
\text { From } 36 \text { to } 55 \text { years - } \\
\mathbf{4 8 , 1 9 \%} \\
\text { Over } 56 \text { years - } \\
\mathbf{3 0 , 3 8 \%}\end{array}$ & $\begin{array}{l}\text { - } \text { Master - } \mathbf{1 0 , 7 8 \%} \\
\text { - } \text { Bachelor - } \mathbf{1 5 , 6 4 \%} \\
\text { - Secondary specialized } \\
\text { education - } \mathbf{2 9 , 3 1 \%} \\
\text { - Secondary education - } \\
\mathbf{3 4 , 7 7 \%} \\
\text { - } \text { Primary education - } \mathbf{7 , 4 4 \%} \\
\text { - Elementary education - } \\
\mathbf{2 , 0 6 \%}\end{array}$ & $\begin{array}{l}\text { - Less than } 1 \text { year - } \mathbf{0 , 9 7 \%} \\
\text { - From } 1 \text { to } 5 \text { years - } \mathbf{2 3 , 6 1 \%} \\
\text { From } 6 \text { to } 15 \text { years - } \mathbf{2 8 , 8 7 \%} \\
\text { - From } 16 \text { to } 35 \text { years - } \\
\mathbf{2 7 , 6 1 \%} \\
\text { - Over } 36 \text { years - } \mathbf{1 8 , 9 4 \%}\end{array}$ & $\begin{array}{l}\text { - Workers - } \mathbf{4 1 , 2 7 \%} \\
\text { - } \text { Employees - } \mathbf{3 4 , 6 6 \%} \\
\text { - } \text { Managers of Inferior } \\
\text { management level - } \\
\mathbf{9 , 2 0 \%} \\
\text { - Managers of } \\
\text { intermediary level - } \\
\mathbf{1 2 , 6 9 \%} \\
\text { - Managers of higher } \\
\text { levels - } \mathbf{2 , 1 8 \%}\end{array}$ \\
\hline
\end{tabular}

Figure 1. Classification of the participants in the study by different criteria

The study is based on a previously developed questionnaire. It presents various statements describing the motivation of the human resources as well as their commitment to the organization in which they work. The participants were asked to rate different statements using a scale of 1 to 10 . /The lowest score was 1 and the highest was $10 \%$.

The work motivation was measured by various statements organized into 10 groups. They present the main aspects of motivation, and namely:

Motivation for work related to the working conditions - expressed by statements such as "The physical conditions at my workplace are good" and "My working hours are convenient for me and my family";

Motivation for work related to remuneration and wages - expressed through statements such as "The income I receive provides me with a good standard of living";

Work motivation related to the content of the tasks - expressed through statements such as "My work is interesting and fascinating", "My job requires me to use the skills and abilities I have", or "My work is strenuous";

Motivation for work related to self-control - expressed through statements such as "I can independently determine the way and the sequence of my tasks";

Feedback motivation for work - expressed through statements such as "I can always judge whether the results I have achieved are good";

$>$ Work motivation related to the organization's policy towards its employees - expressed through statements such as "There is good work organization in my workplace", "The company provides me with the use of additional benefits and perks";

Motivation for work related to the professional and personal development - expressed through statements such as "I have the opportunity to be promoted and to advance in my job";

Motivation for work related to recognition - expressed through statements such as "I am adequately valued and recognized by the management";

$>$ Motivation for work related to the colleagues - expressed through statements such as "the relationship between our team members is good";

Motivation for work related to the managers - expressed by statements such as "My boss is a competent specialist" or "I have a decent and sympathetic boss".

The main aspects revealing the the human resources involvement in the business organizations are directed to:

- the content of the work,

- the surrounding conditions, 
- the relations with the management team,

- the remuneration,

- the relationships with the colleagues,

- the overall satisfaction.

They are expressed through statements related to the possibility of autonomy and control, the responsibility at performance, the ability to use the skills in the work process, the tension at the job and the variety in carrying out the work tasks.

At the analysis of the links between the commitment and the various aspects of the work activities, related to motivation, a factor analysis was also made using the principal components of Varimax rotation. The initial theoretical assumptions are based on the notion that commitment to an organization is a complex psychological entity which is formed under the influence of various factors and therefore has various forms of manifestation of personality behavior at the workplace. As a result, five main factors have been identified which cover the various components of human resource engagement with the business organization.

The first factor involves statements whose content allows us to derive it as a „value of membership“. This factor emphasizes the desire of the individual to be a member of that precise organization due to emotional and moral reasons.

The second factor contains statements related mainly to feelings and emotions leading to different degrees of empathy. For the purposes of the study, it is referred to as „emotional affiliation“.

The content of the third factor reflects the intention to leave or stay in the current organization and the alternatives available to choose among (e.g., ,I think my options are too limited to think of leaving that company“; ,Many things in my life would go wrong if I decided I wanted to leave right now. „) It is referred to as „lack of alternative for leaving“".

The fourth factor covers statements about the value of staying in the organization as a result of the socialization process which leads to the conviction of loyalty and faithfulness to the company. This strong moral expression also gives the name of the factor - „loyalty to the organization“.

The last of the separate factors is related to the possible losses (material and psychological) of leaving the organization (,It would be very difficult for me to leave this company, even if I wanted to"). Therefore, the name of this factor is ,personal sacrifice from leaving the organization“.

Limitations. The research is based on primary survey data from seven companies in five towns in Bulgaria. From this perspective, some of the data may not overlap completely with other organizations in different cities. This is due to the heterogeneous socio-economic conditions in the different regions of Bulgaria, as well as due to a number of other objective and subjective factors.

The survey covers the period September 2018 - February 2019. It is based on a questionnaire specifically designed for the purpose of the study. The interview method is used to clarify the data and information. The statistical data processing is performed through the method of Pearson correlation analysis. The statistical package SPSS 13.0 and Microsoft Office (Word, Excel, Power Point) are used for data processing and analysis.

\section{Results and discussion}

Study of the interaction between the motivation of the human resources and their commitment to the organization 
The data from the study of the interaction between the motivation of the human resources and their involvement in the company show that the first considered aspect of human resources commitment in the business organizations, arising from the content of work, is a statistically significant correlation with all aspects of motivation considered (Table 1). Particularly high correlation coefficients are observed, respectively, with the opportunity for professional and personal development $/ \mathrm{R}=0.583 /$, recognition $/ \mathrm{R}=0.668$, work content $/ \mathrm{R}=0.648 /$ and self-control $/ \mathrm{R}=0.569 /$. Their significance is proved at $\alpha=0.01$. This shows that the more conditions for professional development and self-improvement are created in the organizations, the more the individual is inclined to develop empathy with the conditions offered by the respective organization.

Table 1. Interaction between commitment and the different aspects of work related to motivation

\begin{tabular}{|l|c|c|c|c|c|c|}
\hline Commitment & $\begin{array}{c}\text { Content } \\
\text { of Work }\end{array}$ & $\begin{array}{c}\text { Working } \\
\text { Environment } \\
\text { Conditions }\end{array}$ & $\begin{array}{c}\text { Relations with the } \\
\text { Management Team }\end{array}$ & $\begin{array}{c}\text { Remuneration } \\
\text { of Work }\end{array}$ & $\begin{array}{c}\text { Relations } \\
\text { hips with } \\
\text { Colleagues }\end{array}$ & $\begin{array}{c}\text { Overall } \\
\text { Satisfaction }\end{array}$ \\
\hline Working Conditions & $0,406^{* *}$ & $0,507^{* *}$ & 0,198 & $0,303^{*}$ & 0,106 & 0,143 \\
\hline Remuneration & $0,431^{* *}$ & $0,678^{* *}$ & $0,347^{* *}$ & $0,736^{* *}$ & 0,167 & 0,175 \\
\hline Work Content & $0,648^{* *}$ & $0,395^{* *}$ & $0,469^{* *}$ & $0,326^{* *}$ & 0,221 & $0,384^{* *}$ \\
\hline Self-Control & $0,559^{* *}$ & $0,594^{* *}$ & $0,503^{* *}$ & $0,284^{*}$ & 0,209 & $0,288^{*}$ \\
\hline Feedback & 0,154 & 0,209 & 0,173 & 0,169 & 0,136 & 0,203 \\
\hline Organization Policies & $0,397^{* *}$ & $0,467^{* *}$ & $0,237^{*}$ & $0,323^{* *}$ & 0,183 & 0,188 \\
\hline $\begin{array}{l}\text { Opportunities for Professional and } \\
\text { Personal Development }\end{array}$ & $0,583^{* *}$ & $0,621^{* *}$ & $0,534^{* *}$ & $0,594^{* *}$ & 0,166 & $0,347^{* *}$ \\
\hline Recognition & $0,668^{* *}$ & $0,603^{* *}$ & $0,559^{* *}$ & $0,511^{* *}$ & $0,244^{*}$ & $0,361^{* *}$ \\
\hline Relationship with the Colleagues & $0,386^{* *}$ & $0,326^{* *}$ & $0,426^{* *}$ & $0,257^{*}$ & 0,148 & $0,246^{*}$ \\
\hline Relationship with the Management & $0,434^{* *}$ & $0,515^{* *}$ & $0,701^{* *}$ & $0,258^{*}$ & $0,317^{* *}$ & $0,358^{* *}$ \\
\hline
\end{tabular}

Source: Author's data,

Note:* The correlation is proven at 0.05 levels; ${ }^{* *}$ The correlation is proven at 0.01 levels

Similar results are also observed in the interrelationship of the human resource commitment, resulting from the surrounding conditions, and the work motivation. In order to be achieved high organizational efficiency and development of the business organizations, a satisfactory payment of the invested labor is required $/ \mathrm{R}=0.678$ at $\alpha=0.01 /$, creating conditions for professional and personal development $/ \mathrm{R}=0.621$ at $\alpha=0.01 /$, recognition $/ \mathrm{R}=0.603$ at $\alpha=0.01 /$ and self-control $/ \mathrm{R}=0.594$ at $\alpha=0.01 /$. This implies creating a work environment which provides freedom, flexibility, autonomy and responsibility. All of the above listed leads to increased organizational efficiency and success.

Usually the relationships of the employees with the management team are perceived as a good opportunity for evaluation and feedback regarding the work and the efforts put into it. The data from this research show that high correlation coefficients for almost all aspects of motivation are found in the relationship between human resources involvement resulting from the relationships with the management and the work motivation. Particularly strong proportional dependence is observed in professional and personal development opportunities with $\mathrm{R}=0.534$ at $\alpha=0.01$ and recognition with $\mathrm{R}=0.559$ at $\alpha=0.01$. The interviewed associate these two aspects of motivation with the management team, which requires excellent communication between the different levels in the business organizations, as well as clear regulation of the opportunities for professional and personal development.

An important aspect of revealing the involvement of the human resources in the surveyed business organizations and its interaction with work motivation is the remuneration (material benefits). Good pay also requires a job well done. It is a recognition of the work done and the results achieved. This study finds a statistically proven relationship between remuneration and all aspects of the motivation. Particularly high correlation coefficients are reported at the development opportunities $/ \mathrm{R}=0.594$ at $\alpha=0.01 /$ and recognition $/ \mathrm{R}=0.511$ at $\alpha=0.01 /$. The satisfactory payment is directly linked to the professional and personal development opportunities and is an acknowledgment of excellent work. This reinforces the empathy of the human resources with the problems and development of the company. 
When analyzing the relationship between the human resources involvement resulting from the relationships with colleagues and the work motivation, no statistically proven correlation coefficients are considered. The aspects related to the relations with the management team and the recognition are exceptions. They demonstrate statistically proven but low correlation coefficients.

Of interest are the results of the analysis of the last considered aspect of the human resources commitment resulting from the overall satisfaction. It does not exhibit statistically proven correlation coefficients in terms of payment and working conditions, as well as with regard to the organization's policy and the feedback. The overall satisfaction is directly correlated with the content of work with $\mathrm{R}=0.384$ at $\alpha=0.01$, the development opportunities with $\mathrm{R}=0.347$ at $\alpha=0.01$, the recognition with $\mathrm{R}=0.361$ at $\alpha=0.01$ and relations with the management team with $\mathrm{R}=$ 0.358 at $\alpha=0.01$. From the data we can judge that the employees of the business organizations feel satisfied in an environment which offers them the opportunity for professional and personal development and which brings them well-deserved recognition. This is a guarantee for achieving high levels of organizational efficiency and success.

\section{Analysis of the factors of the interaction between the different aspects of empathy and the different aspects of work related to motivation}

Interesting results are also observed in the factor analysis (Table 2). The study of the first factor shows a strong interaction of the value of membership with the motivating factor "working conditions" $/ \mathrm{R}=0.561$ at $\alpha=0.01$ /. The more valued an organization's membership is, the more the environment is perceived to be favorable in terms of the opportunities it offers for promotion and growth, thus achieving organizational effectiveness and success. A statistically significant correlation is also observed in the content of work $/ R=425$ at $\alpha=0.01 /$ and recognition $/ \mathrm{R}=373$ at $\alpha=0.01 /$. The content of the work greatly enhances the value of membership. Perceiving the job as the enabler of autonomy, control, feedback, and utilization of abilities and skills, guarantees an increased desire to be and remain a member of an company. Statistically proven but low correlation coefficients are also observed in opportunities for development, relations with management and payment.

The emotional affiliation is largely related to almost all aspects of the motivation, with correlations here having similar values to those of the value of membership. The sense of emotional attachment to the organization greatly enhances the motivating force of the opportunity for professional and personal growth $/ \mathrm{R}=455$ at $\alpha=0.01 /$, recognition $/ \mathrm{R}=457$ at $\alpha=0.01 /$ and the content of work $/ \mathrm{R}=489$ at $\alpha=0.01 /$. The more the employees are motivated by the various aspects of the environment, the more they perceive the organization as a large family of which they are a part. Remuneration motivation is also significantly associated with experiencing emotional attachment to the organization $-\mathrm{R}=466$ at $\alpha=0.01$.

Table 2. Factor analysis of the commitment and the different aspects of the work related to motivation

\begin{tabular}{|l|c|c|c|c|c|}
\hline Commitment Factors & $\begin{array}{c}\text { Value of } \\
\text { Membership }\end{array}$ & $\begin{array}{c}\text { Emotional } \\
\text { Affiliation }\end{array}$ & $\begin{array}{c}\text { Lack of Alternatives } \\
\text { for Leaving }\end{array}$ & $\begin{array}{c}\text { Loyalty to the } \\
\text { Organization }\end{array}$ & $\begin{array}{c}\text { Personal Sacrifice from } \\
\text { Leaving the Organization }\end{array}$ \\
\hline Working Conditions & $0,561^{* *}$ & $0,532^{* *}$ & $0,407^{* *}$ & $0,418^{* *}$ & 0,261 \\
\hline Remuneration & $0,319^{*}$ & $0,466^{* *}$ & $0,324^{*}$ & 0,189 & $0,298^{*}$ \\
\hline Work Content & $0,425^{* *}$ & $0,489^{* *}$ & $0,365^{*}$ & 0,263 & $0,358^{*}$ \\
\hline Self-Control & 0,268 & 0,198 & 0,174 & 0,197 & 0,223 \\
\hline Feedback & 0,186 & 0,207 & 0,118 & 0,264 & 0,187 \\
\hline Organization Policies & 0,203 & 0,163 & $0,423^{* *}$ & $0,489^{* *}$ & 0,164 \\
\hline $\begin{array}{l}\text { Opportunities for Professional } \\
\text { and Personal Development }\end{array}$ & $0,271^{*}$ & $0,455^{* *}$ & 0,248 & $0,437^{* *}$ & 0,253 \\
\hline Recognition & $0,373^{* *}$ & $0,457^{* *}$ & $0,468^{* *}$ & $0,368^{*}$ & $0,539^{* *}$ \\
\hline Relationship with the Colleagues & $0,328^{*}$ & $0,409^{* *}$ & 0,266 & $0,483^{* *}$ & $0,411^{* *}$ \\
\hline Relationship with the Management & $0,352^{*}$ & 0,194 & $0,368^{*}$ & $0,501^{* *}$ & 0,224 \\
\hline
\end{tabular}


The lack of an alternative for leaving interacts particularly strongly with the working conditions with $\mathrm{R}=407$, recognition $R=468$, and the company policy $R=423$. Their significance is proven at $\alpha=0.01$. Any organization which seeks to create a work environment which offers freedom, flexibility, autonomy and responsibility, gives its employees a reason to all the more appreciate the lack of alternatives.

Loyalty is primarily related to the motivating force of the working conditions $/ \mathrm{R}=418$ at $\alpha=0.01$, the policy of the organization $/ \mathrm{R}=489$ at $\alpha=0.01 /$, the relations with colleagues $/ \mathrm{R}=483$ at $\alpha=0.01 /$ and the management $/ \mathrm{R}=501$ at $\alpha=0.01 /$, which shows that the influence of the external aspects of labor dominates. Contrary to the expectations, it turns out that high loyalty is maintained mainly by favorable social (satisfaction with management and colleagues) and organizational (opportunity for promotion, recognition and growth, physical working conditions) factors. Loyalty does not prove the interaction with salary, job content or feedback. From all this we can conclude that the factors of loyalty formation are not material but rather social and are directly related to the employees' sense of acceptance.

The personal sacrifice from leaving the organization factor interacts particularly strongly with the recognition and relationships with colleagues. They show a proportional interdependence, proven by $\mathrm{R}=539$ and $\mathrm{R}=411$ at $\alpha=0.01$, respectively. The satisfaction with the job content $/ \mathrm{R}=358$ at $\alpha=0.05 /$ and remuneration $/ R=298$ at $\alpha=0.05 /$ are equally related to the personal sacrifice of leaving. On the one hand, they increase the feeling of the individuals that they will lose something valuable on leaving. On the other hand, there remains the dissatisfaction with pay and the opportunities for promotion and growth. This reduces the sense of sacrifice which the individuals would experience upon leaving the organization, and this greatly facilitates their intentions to leave.

\section{Conclusions}

As a result of the data presented and the analysis made about the relationship between the motivation of the human resources and their commitment to the business organization, the following important conclusions can be drawn:

- The more the conditions for professional development and self-improvement of the human resources are enhanced in the business organizations, the more the person is inclined to develop a commitment to the conditions offered by the respective organization, which guarantees the achievement of organizational efficiency and success;

- The achievement of high organizational efficiency and development of the companies requires the creation of a working environment which provides freedom, flexibility, decision-making capacity and responsibility;

- The relationships of the employees with the management team are perceived as a good opportunity to evaluate the human resources and a feedback regarding the work and the efforts put into it;

- Good remuneration is directly linked to professional and personal development opportunities and is an acknowledgment of excellent work. This strengthens the human resources involvement in the problems and the development of the business entities;

The employees of a company feel satisfied in an environment which offers them the opportunity for professional and personal development that brings them well-deserved recognition, which is a guarantee for achieving organizational efficiency and success.

Good conditions and satisfaction with the work performed is the success of the entire enterprise. It favors dynamic development and stimulates innovation (Pukala, 2016, Pukala, 2019). So it is a source of organization'ssuccess.

\section{References}

Aktan B., Turen S., Tvaronaviciene M., Celik S., Alsadeh H.A. 2018. Corporate governance and performance of the financial firms in Bahrain, Polish Journal of Management Studies, 17(1), 39-58. https://doi.org/10.17512/pjms.2018.17.1.04 
Androniceanu, A., Tvaronavičienè, M. 2019. Developing a holistic system for social assistance services based on effective and sustainable partnerships. Administratiesi Management Public, (33), 103-118. https://doi.org/10.24818/amp/2019.33-06

Bernardi, A. 2019. The capability approach and organizational climate as tools to study occupational health and safety. Insights into Regional Development, 1(2), 155-169. https://doi.org/10.9770/ird.2019.1.2(6)

Bogomolov, A.B, Nevezhin, V.P., Chagovets, L.O. Using econometric modeling in likelihood assessing of investment activity risks. IEEE First International Conference on System Analysis \& Intelligent Computing (SAIC-2018)) Kyiv, Ukraine 08-12 October 2018, IEEE Catalog Number: CFP18SUA-CDR, ISBN: 978-1-5386-7195-5, Institute of Electrical and Electronics Engineers Inc., http://doi. org/10.1109/SAIC.2018.8516898

Borisov, A., Narozhnaia, D., Tarando, E., Vorontsov, A., Pruel, N., Nikiforova, O. (2018). Destructive motivation of personnel: a case study of Russian commertcial companies. Entrepreneurship and Sustainability Issues, 6(1), 253-267. http://doi.org/10.9770/ jesi.2018.6.1(16)

Bublienė, R., Vinogradova, I., Tvaronavičienè, M.. Monni, S. 2019. Legal form determination for the development of clusters' activities, Insights into Regional Development, 1(3), 244-258. https://doi.org/10.9770/ird.2019.1.3(5)

Davidkov, Ts., (2009), National and Organizational Culture, Paradigm, Sofia

Girdzijauskaite, E., Radzeviciene, A., Jakubavicius, A. 2019. Impact of international branch campus KPIs on the university competitiveness: FARE method. Insights into Regional Development, 1(2), 171-180. https://doi.org/10.9770/ird.2019.1.2(7)

Gryshova, I. Y., Mityay, O.V., Kuzhel, V.V. (2016a). Competitive position stability of agricultural sector of Ukraine at internal and external markets. Actual Problems of Economics, (177), 66-73.

Gryshova, I. Yu. Naumov, O. Shabatura T. (2016b). Brand capitalization as a tool to maximize business value. Scientific Bulletin of Polissia, 3(7), 168-175.

Gryshova, I., Petrova, M., Tepavicharova, M., Diachenko, A., Gutsul, T. 2019. A model for selection of a management team to ensure the sustainability and development of the business organizations. Entrepreneurship and Sustainability Issues, 7(1), 690-703. http://doi. org/10.9770/jesi.2019.7.1(49)

Hermawan, A., Gunardi, A. (2019). Motivation for disclosure of corporate social responsibility: evidence from banking industry in Indonesia. Entrepreneurship and Sustainability Issues, 6(3), 1097-1106. http://doi.org/10.9770/jesi.2019.6.3(17)

Hlushko, O., Gryshova, I., Shcherbata, M. (2015). Enterprises' economic sustainability assessment on the basis of performance indicators. Economic Annals-XXI, 155(11-12), 82-86.

Ilieva, S. (2009). Values and work motivation. The University of St. Kliment Ohridski, Sofia

Islamgaleyev A.H., Uruzbayeva N.A. (2018). Using a customer-oriented approach in sales management in the metal trading market of the Republic of Kazakhstan. Vienna: Premier Publishing s.r.o. 184 p.

Islamgaleyev, A. (2018a). Development of model of encouragement of sale managers under the conditions of differentiation of business in metal trading. Innovation Processes in the context of Globalization of the World Economy: Challenges, Trends, Prospects (IPEG-2018) PRAGA, ISBN 978-80-7526-316-2

Islamgaleyev, A. (2018b) Target client group analysis at “Kazpromkomplex" LLP. Minzu University of China «Scientific research of the SCO countries: synergy and integration» June 29-30, pp.29-40, ISBN 978-5-905695-70-4. Beijing

Kolodiziev, O.M., Boyko, N.O. (2015). Formation of customer capital management strategies at engineering enterprise. Actual Problems of Economics, 174(12), 168-180

Koval, V., Duginets, G., Plekhanova, O., Antonov, A., Petrova, M. (2019). On the supranational and national level of global value chain management. Entrepreneurship and Sustainability, 6(4), 1922-1937. http://doi.org/10.9770/jesi.2019.6.4(27)

Koval, V., Pukała, R. (2017). Implementation of regulatory policy in economic activity: development of the institute regulatory impact assessment. Economics. Ecology. Socium, 1(1), 24-32.

Labunska Sv., Petrova M., Prokopishyna O. (2017). Asset and cost management for innovation activity. Economic Annals - XXI, 165(5-6), 13-18. https://doi.org/10.21003/ea.V165-03

Labunska, S., Karaszewski, R., Prokopishyna, O., Iermachenko, I (2019). Cognitive analytical tools for cost management of innovation activity. Problems and Perspectives in Management, 17(1), 395-407. http://dx.doi.org/10.21511/ppm.17(1).2019.34 
Lazarova, T., Zhelyazkova, V., Vazov, R. (2015). Innovation leadership as a key concept in entrepreneurship. Proceedings of International Conference for Entrepreneurship, Innovation and Regional Development ICEIRD 2015, University of Sheffield, pp.275-287

Lorincová, S., Hitka, M., Bajzíková, L', Weberová, D. (2019). Are the motivational preferences of employees working in small enterprises in Slovakia changing in time. Entrepreneurship and Sustainability Issues, 6(4), 1618-1635. https://doi.org/10.9770/jesi.2019.6.4(5)

Lukjanova, J. (2019). Problems and Trends of Regional Tourism Development in Latvia. Economics. Ecology. Socium 2019, 3 , p.1-11. Institute of Market Problems and Economic-and-Ecological Research of the National Academy of Sciences of Ukraine, Odessa, Ukraine. ISSN-L: 2616-7107

Malyarets, L.; Dorokhov, O.; Koybichuk, V.; Dorokhova, L. (2019). Obtaining a Generalized Index of Bank Competitiveness Using a Fuzzy Approach. Journal of Central Banking Theory and Practice, 8(1), 163-182. https://doi.org/10.2478/jcbtp-2019-0008

Odinokova, T. (2019). Tourism cluster as a form of innovation activity. Economics. Ecology. Socium, 3 (2), 1-11.

Odinokova, T., Bozhinova, M., Petrova, M. (2018). Promotion of Innovative Entrepreneurship under Sustainable Development. E3S Web Conferences, Volume 41, 04015. IIIrd International Innovative Mining Symposium, Kemerovo, Russian Federation, https://doi. org/10.1051/e3sconf/20184104015

Petrova M., Dekhtyar N., Klok O., Loseva O. (2018). Regional tourism infrastructure development in the state strategies. Problems and Perspectives in Management, 16(4), 259-274. https://doi:10.21511/ppm.16(4).2018.22

Petrova M., Tepavicharova M., Dikova L. (2018). Possibilities for human capital development in the mining and quarrying sector in Bulgaria. E3S Web of Conferences Volume 41, 04017, IIIrd International Innovative Mining Symposium, Kemerovo, Russian Federation, https://doi.org/10.1051/e3sconf/20184104017

Ponomarenko, V., Gontareva, I. (2017). The system of causal connections between entrepreneurial activity and economic development. Economic Annals - XXI, 165(5-6), 4-7. https://doi.org/10.21003/ea.V165-01

Ponomarenko, V., Kolodiziev, O., Chmutova, I. (2017). Benchmarking of bank performance using the life cycle concept and the DEA approach. Banks and Bank Systems, 12(3), 74-86.

Pukala, R (2019). Start-ups as an element supporting the development of the mining and energysector. IVth International Innovative Mining Symposium E3S Web of Conferences, Vol. 105. October 14-16, Kemerovo, Russian Federation, 1-6. https://doi.org/10.1051/ e3sconf/201910504015

Pukala, R. (2016). Use of neural networks in riskassessment and optimization of insurancecover in innovative enterprises. Engineering Management in Production and Services, 8(3), 43-56.

Pukala, R.; Petrova, M. (2019), Application of the AHP Method to Select anOptimal Source of FinancingInnovation in the MiningSector. IVth International Innovative Mining Symposium E3S Web of Conferences, Vol. 105. Kemerovo, Russian Federation, 1-6. https:// doi.org/10.1051/e3sconf/201910504034.

Sushchenko, O., Trunina, I., Klok, O., Loseva, O. (2019). Management technologies of ensuring environmental protection as the territory development strategic priority. SHS Web of Conferences 61, 01026, Volume 61, 2019. Innovative Economic Symposium 2018 Milestones and Trends of World Economy (IES2018). https://doi.org/10.1051/shsconf/20196101026

Tumalavičius, V., Veikša, I., Načisčionis, J., Zahars, V., \& Draskovic, V. (2017). Issues of the state and society security (part i): ensuring public security in the fight against crime. Journal of Security and Sustainability Issues, 6(3), 401-418. http://doi.org/10.9770/ jssi.2017.6.3(7)

Tvaronavičienè, M., Razminienè, K. (2017). Towards competitive regional development through clusters: approaches to their performance evaluation. Journal of Competitiveness, 9(4), 133 - 147, https://doi.org/10.7441/joc.2017.04.09

Uteubayev, T., Petrova, M.M., Lyubenova, I. 2018. Training of qualified specialists in the process of their education at the university: the role of the public-private partnership. CBU International Conference Proceedings Pages, pp.491-495.

Vazov R. (2019). Inovative Approaches to Insurance Company Cash Flow Management (contemporary theoretical aspects). Sofia: VUZF Publishing House «St. Grigorii Bogoslov», ISBN: 978-954-8590-54-9, 136 p.

Zahars, V., Stivrenieks, M. (2018). Security, surveillance and re-socialization aspects in Center for drug addicts of Olaine City Prison in Latvia. Journal of Security and Sustainability Issues, 7 (4), 643-656. https://doi.org/10.9770/jssi.2018.7.4(3)

Zemlickiene, V., Mačiulis, A., Tvaronavičienè, M. (2017). Factors impacting the commercial potential of technologies: expert approach, Technological and Economic Development of Economy, 23(2), 410-427 http://dx.doi.org/10.3846/20294913.2016.1271061 
Mariana PETROVA, Professor, D.Sc in Physics and Mathematics, Assoc.Prof. St. Cyril and St. Methodius University of Veliko Tarnovo, Bulgaria; Professor Economics and Management in Department of Management, ISMA University, Riga, Latvia. Research interests: management of IT processes, project and services, business administration, modern information systems and innovations, knowledge economy, sustainable development.

ORCID ID: https://orcid.org/0000-0003-1531-4312

Viktor KOVAL, Dr. Sc. (Economics), Professor of the Department of Applied Economics, Odessa Institute of Trade and Economics of Kyiv National University of Trade and Economics. Research interests: economics of industry, production efficiency, environmental management, tourism.

ORCID ID: orcid.org/0000-0003-2562-4373

Milena TEPAVISHAROVA, Professor of Business Enterprise and Innovation, Ph.D, Dean Faculty of Economics and Management, Higher School of Security and Economics, Plovdiv, Bulgaria

Research interests: entrepreneurship and regional development; innovation and small firms; small firm internationalization; sustainability. ORCID ID: https://orcid.org/0000-0003-3759-5426

Anastasiia ZERKAL, Deputy Head, Associate Professor of Finance, Accounting and Taxation Department, Phd in Economics, Associate Professor Classic Private University, Zaporizhzhya, Ukraine.

Research interests: solving issues of formation and implementation of the public policy, including the educational public policy.

ORCID: https://orcid.org/0000-0002-3155-1302

Andrii RADCHENKO, Graduate student of Zaporizhzhia Polytechnic National University, Ukraine. Research interests: management, policy.

ORCID ID: https://orcid.org/0000-0002-1010-9937

Nataliia BONDARCHUK, Professor of the Department Accounting, taxation and financial-security management, Doctor of Sciences in Public Administration, Professor, Dnipro State Agrarian and Economic University, Ukraine.

Research interests: study of the foreign experience in policy implementation in the field of higher education and the possibility of its adaptation to modern development requirements.

ORCID: https://orcid.org/0000-0002-0418-5239

Register for an ORCID ID:

https://orcid.org/register

This work is licensed under the Creative Commons Attribution International License (CC BY).

http://creativecommons.org/licenses/by/4.0/ 